\title{
Did You Try Our Good Smoked Ham? Assessing the Quality of Translation as Cross-Cultural Mediation on Croatian Tourist Board Websites
}

\begin{abstract}
Tourist discourse has been recognized as a specialized type of cross-cultural communication. Thus, successful translation of tourist texts assumes that translators act as cross-cultural mediators on a number of levels. The rather low quality of translation in the tourism sector has been pointed out by several Translation Studies scholars. However, not much systematic empirical research on the quality of translation in this sector has been carried out. This paper analyses a corpus of multilingual websites produced by Croatian tourist boards. In the analysis of the data I rely on the criteria for assessing translation quality of web translation developed by Pierini (2007), and place a special focus on the achievement of pragmatic level equivalence between source and target texts as a major criterion of successful cross-cultural communication in the translation of tourism discourse.
\end{abstract}

Keywords: translation quality, tourist discourse, multilingual websites

\section{Ste poskusili našo okusno prekajeno šunko? Ocenjevanje kakovosti prevoda kot medkulturnega posredovanja na spletnih mestih Hrvaške turistične skupnosti}

\section{IZVLEČEK}

Turistični diskurz je prepoznan kot posebna vrsta medkulturne komunikacije, zato uspešen prevod turističnih besedil predpostavlja vlogo prevajalcev kot medkulturnih posrednikov na več ravneh. Precej nizko kakovost prevodov v turističnem sektorju so izpostavili številni prevodoslovci, a kljub temu v tem sektorju ni bilo izvedenih veliko sistematičnih empiričnih raziskav o kakovosti prevodov. V članku je analiziran korpus večjezičnih spletnih mest Hrvaške turistične skupnosti. Pri analizi podatkov se zanašam na merila ocenjevanja kakovosti spletnih prevodov, ki jih je razvila Pierini (2007), ter se pri tem posebej osredotočam na doseganje pragmatične stopnje ekvivalence izvirnih in ciljnih besedil kot glavnega merila uspešne medkulturne komunikacije v prevodih turističnega diskurza.

Ključne besede: kakovost prevodov, turistični diskurz, večjezična spletna mesta 


\section{Introduction}

In his seminal book on the language of tourism, Dann $(1996,6)$ predicted that it would soon become "a language of cyberspace", and the widespread use of the Internet for tourism promotion over the last decades is aptly described as the "migration [of tourism texts] to the web" (Francesconi 2014, 5).

The broad aim of this study is to explore the quality of translations into English of Croatian tourist boards' promotional material published on the web. It consists of two parts: first, in a brief overview of the approaches to assessing translation quality, both in the academic community and the translation industry, the emphasis is placed on the model developed by House $(1997,2015)$, whose key concepts, such as "overtly erroneous" errors and "covertly erroneous"1 errors, are used in the analysis of the corpus and on the framework for quality assessment of translations of tourism texts on the web proposed by Pierini (2007). Next, Pierini's definition of quality is presented, followed by the formulation of the criteria for assessing quality in the analysed corpus. The outlined criteria that take into account the specific features of translating tourism promotional texts on the one hand, while on the other the specific features of translating texts for the web are applied in the qualitative analysis of the corpus of texts published on Croatian tourist boards' websites.

For the purposes of this research a small-size corpus consisting of six source texts (STs) and six target texts (TTs) published on the websites of Croatian tourist boards was compiled. In order to compile a sample of comparable texts that would be manageable for conducting a qualitative analysis, I focussed on pages that address the theme of gastronomy. Gastronomy has recently gained a growing importance in the promotion of tourist destinations. Among other factors, this is due to the fact that today's "new tourist" is constructed as an active participant in the experience of travelling and visiting destinations. At the same time, as has been pointed out by tourism studies scholars (Van Westering 1999), gastronomy and culture are closely intertwined. Consequently, it seems plausible to assume that texts related to gastronomy written for the purposes of tourism promotion will contain a large number of culturally specific references or exotisms, which presents a challenge for the translator in terms of cross-cultural transfer. The corpus is described in more detail in Section 4.3.

The formulated criteria are applied on the corpus of authentic translations in order to test the criteria and their validity for assessing the quality of tourism texts translations on the web, and to shed light on the quality of real-world translations of this type.

\section{Features of English Tourism Discourse}

Since Dann's pioneering study on the language of tourism various aspects of the language used in the tourism sector have been continuously researched from a wide range of perspectives. Due to space restrictions, I will mention just a few contributions that may illustrate a range of perspectives brought together in the study of tourism discourse: the features of the discourse of tourism as a type of specialized discourse (Calvi 2006; Cappelli 2006 and 2008; Gotti

For the sake of simplicity, in the analysis I will refer to overt and covert errors instead of using House's terms. 
2006; Nigro 2005, 2012); linguistic strategies prominent in tourism discourse (Mocini 2005, 2013; Francesconi 2008; Agorni 2012, 2016; Manca 2016); multimodal analysis of various digital genres (Yui Ling Ip 2008; Francesconi 2014; Denti 2015) and the use of tourist texts in EFL and translation teaching (Gandin 2016). Although the literature on tourism discourse is vast, only a few studies have focussed on Croatian tourism discourse, mainly from the perspective of critical discourse analysis (Fox 1999, 2004, 2007).

In its communication the tourist industry inevitably relies on translation. As Sulaiman and Wilson $(2019,38)$ point out, tourism promotional materials are "perhaps one of the most translated types of texts in the world today". Accordingly, various aspects of translation of tourism texts have attracted considerable interest among translation scholars (Agorni 2012, 2016; Cappelli 2008; Francesconi 2014; Hatim 2004; Hickey 2004; Kelly 1997; Manca 2016; Pierini 2007, 2009; Snell-Hornby 1999; Sumberg 2004; Valdeón 2009).

Especially pertinent to my study are insights gained by empirical research into the discursive and linguistic features of tourism texts written in English. Dann provides the first systematic approach to the language of tourism, emphasizing its promotional function, which "attempts to persuade, lure, woo and seduce millions of human beings, and, in doing so, convert them from potential into actual clients" $(1996,2)$.

One of the most prominent linguistic features of English tourism discourse is the use of an informal style, i.e., a tendency to use short and simple sentences. Another important feature documented in previous research on English tourism discourse is the use of "egotargeting" devices, i.e., the employment of "lexical devices typical of a conversational style" such as the use of first and second person (plural and singular) pronouns, interjections, possessive adjectives and pronouns, which allow for direct addressing of readers. (Dann 1996, 185-88). It should be pointed out that these features are even more accentuated in the texts that appear online, which seek to reinforce the impression of interpersonal communication (Janoschka 2004, 24).

On the lexical level, its most prominent feature is the recurrent use of highly positive evaluative adjectives (outstanding, spectacular, exotic, colourful), which are often used as absolute superlatives (for example, the most exciting, the most thrilling, the most spectacular) or in superlative structures. A fine example of the typical use of adjectives is provided by Durán Muñoz:

Let us explore the most thrilling, electrifying and mind blowing adventurous activities $[\ldots]^{2}(2019,355)$

In addition, evaluative adjectives are often combined with pre-modifying adverbs that intensify their meaning, such as truly unique experience, absolutely spectacular, highly experienced instructor (see Durán Muñoz 2019, 356). Further, such adjectives are often used cumulatively, as in the following examples extracted from the English web 2015 corpus:

Italics are included by Durán Muńoz. The examples are extracted from the ADVENCOR corpus of texts in English, compiled by Durán Muñoz. 
Every villa at this hotel offers views of the spectacular and breathtaking ocean and has direct access to the lagoon. (www.maldivesbeachresorts.org)

or

The Beauty of Plett is breathtaking and absolutely spectacular. (https://www.southafrica.to)

This feature is closely related to Dann's notion of euphoria (1996, 65), i.e., the tendency of the language of tourism "to speak only in positive and glowing terms of the service and attractions it seeks to promote" using superlatives, hyperboles and other linguistic devices to emphasize the uniqueness of the destination.

\section{Translation Quality}

The thorny issue of the evaluation of translation quality has been addressed from a number of perspectives and with a number of distinct goals, characterized by a lack of consensus on what constitutes quality in translation ${ }^{3}$. In the academic context, the interest in quality assessment is often motivated by the needs of translator training: how to evaluate translations in order to be able to assess them and give feedback to students and novice translators. On the other hand, the processes of globalization and digitization have brought about an unprecedented surge in demand for translation, in particular from and into English. Owing to recent technological advances it has become possible to respond to the ever-growing global demand for translated texts. However, it seems that the surge in the volume of translation activity has not resulted in the marginalization of the discussion on quality in the industry sector. Rather, the increase in the demand for translation is complemented with the emphasis on translation quality issues.

Due to space limitations, I will briefly present only House's model of translation quality assessment $(1997,2015)$, as some of its major concepts are used in this research. ${ }^{4}$ House's model was introduced in 1977, and revised in 1997 and 2015, with its main categories remaining in place. The main concepts underpinning her model are the typology of translations (overt and covert translation), the concept of cultural filter and the classification of translation errors. Overt translation is particularly suitable for texts that are specifically tied to the source culture, such as political speeches, sermons, literary texts, etc. As House (2015, 54) explains, covert translation is:

a translation which enjoys the status of an original source text in the target culture. The translation is covert because it is not marked pragmatically as a translation text of a source text but may, conceivably, have been created in its own right. (My emphasis)

In House's words, tourism texts are among those that lend themselves to covert translation, whose function is "to imitate the original's function in a different discourse frame" (1997, 29). Such texts present "more difficulties, and many more subtle, cultural translation problems than those encountered in the case of overt translation" $(1997,56)$. In a covert

\footnotetext{
3 As it is pointed out by Colina, "[ $\mathrm{t}$ ] he lack of consensus on how quality may be evaluated stems to a large extent from disagreements over the concept of translation and from the controversial and relative nature of quality, which is ultimately assessed on the basis of social, historical and culturally based values and priorities" $(2020,458)$.

4 For comprehensive overviews of other "academic" or "theoretical" models see Depraetere (2011) and Drugan (2013).
} 
translation, translators have to apply cultural filters in order to account for "different cultural presuppositions" and meet "the needs of the target language addressees in their cultural setting, and in order to keep the textual function equivalent in source and target cultures" $(1997,56)$. In short, the application of House's fully developed and revised model includes an analysis of the ST in order to establish its function and textual profile and a comparison of the ST and the TT at three levels: language/text, register and genre. An analysis of the ST profile is conducted in order to provide a "statement of function". The same process is then carried out for the TT, and both ST and TT profiles are compared, which produces a statement of mismatches or errors that can be categorized as covertly (at the level of register and genre) or overtly (denotative meaning at the text level) erroneous errors. It is at the end of this process that a statement of translation quality can be made.

\subsection{Approaching Quality in Translations of Tourism Texts}

A number of authors (Duff, 1981; Newmark 1991, 1993; Nord 1991; Kelly 1997; SnellHornby 1999; Pierini 2007; Durán Muñoz 2011) address the quality of tourism text translations, which is generally considered to be deplorable. Duff (1981) and Newmark (1991) point to the poor quality of translations of tourism texts, and argue that this is due to the fact that translation of tourism materials is often done into the translator's non-native language. On the other hand, Nord (1991), Snell-Hornby (1999) and Kelly (1997) see the reason for poor quality in the fact that very often tourism texts are not translated by professional translators.

According to Durán Muñoz $(2011,40)$, non-professional translators are engaged because the language of tourism is not recognized as a specialized discourse, the dominant attitude being that "anyone can do it because it is very easy". Pierini shares this view and emphasizes that

[t]he complexity of promotional tourist discourse is underestimated by clients and translators: it may appear to be deceptively easy to translate with its extensive use of general language; yet, it is a specialized discourse with specific linguistic/cultural features. (2007, 99). (My emphasis)

Challenges for translators also stem from the fact that tourism materials are strongly culturebound (see Snell-Hornby 1999). On the content level, this is evident in a considerable difference in "information load" between STs and TTs. ST readers have better background knowledge about the destination promoted than TT readers. Therefore, there is a need for "the adaptation of information load" (Kelly 1997, 36), taking care that added information is "dosified in some way to prevent an overload which could lead to a breakdown in communication" (1997, 36). Further, there is a difference in the kind of information that source and target readers expect to find in tourist brochures, which depends on their previous textual experience, i.e., on "the reader's knowledge of text conventions firstly in her own language and culture" $(1997,36)$. As for the differences at the level of style, Kelly emphasizes her "targeteer" position, according to which a successful translation would entail adaptation to the stylistic conventions of texts written in the target language (TL). Readily observable differences between Spanish and English tourism texts are related to tenor: while in Spanish texts the reader is rarely directly addressed and the relation established is rather formal 
(marked, for example, by the use of third person singular pronoun Usted when readers are directly addressed), in English texts the relationship with the reader is less formal, as is visible in the frequent use of personal pronouns and imperatives.

Snell-Hornby (1999) also sees the problem in the lack of adaptation in translations of tourist brochures. She argues that though operative function is dominant in tourist brochures, the effect of tourist texts is a result of "an interplay of all three textual functions: informative, expressive and operative." $(1999,96)$. Her analysis of a multilingual tourist brochure for a Spanish hotel shows that all three translations (into English, German and French) can be described as "literal transcodings containing elementary language errors in grammar, lexis and syntax. They all lack coherence and textual cohesion and for that reason alone fail to function as texts" $(1999,98)$. These deficiencies could be overcome with a holistic approach to translation in which "the task of the translator [is ] not to find an individual equivalent for each of the devices, but to create a text, based on the given information, which would rouse the burning desire in the target reader's mind to visit the place advertised" $(1999,100)$.

\subsection{Quality in Translations of Tourism Texts on the Web}

According to Francesconi $(2014,5)$, "migration to the web" is a major aspect of contemporary tourism communication, closely linked to the enhancement of its multimodal character accompanied with interactive features, enabled by the potentials of the web 2.0 technology. Some aspects of the fact that traditional channels of communication have been replaced with digital channels have already received scholarly attention (Yui Ling Ip 2008; Francesconi 2014; Denti 2015). However, not much attention has been paid to quality in the translation of tourism texts published on the web, though the translation industry depends heavily on the translation of web content.

Despite the multimodal character of online content, the language content published on the web is of crucial importance for the success of communication, and consequently of business. Cappelli illustrates this point by citing a research project conducted in Germany on the websites of several banks, which found "that the linguistic quality of the website is perceived iconically in line with the supposed quality of the business or service offered" $(2008,98)$. A good case in point is provided by Munday $(2004,209)$ in his discussion of translating advertising texts:

One example given is that of Electricité de France, which spent over $£ 100,000$ on advertising space but just $£ 60$ on the translation of the copy. Failure to stress the purpose of the translation, and failure to employ a native speaker, meant that unidiomatic phrases such as "EdF offers competitive energetic solutions" appeared in the TT, undermining the professional image of the company.

\section{Aims and Methodology}

The aim of this study is to explore the quality of tourism text translations from Croatian into English published on the web taking into account the specific features of translating for the web on the one hand, and of translating tourism promotional texts on the other. 
The necessary prerequisite for assessment of translation quality is the definition of what is assumed to constitute quality and the formulation of criteria to be applied.

\subsection{Working Definition of Translation Quality}

As has already been pointed out, a general and universally applicable definition of translation quality is unattainable. In this study, I have adopted Pierini's (2007) working definition of quality tailored to translations of texts belonging to a specific discourse (tourism) and specific medium (the web). In her study of a corpus of UK and Italian web sites she argues that in web translation "linguistic criteria, which still remain relevant, are no longer the only parameters on which assessment can rely" $(2007,91)$. In line with this, the author defines translation quality of translated tourism texts on the web as follows:

The TT shows a good quality when it is a native-like text, well-written according to the genre style and web writing style, achieves the intended effect (persuasion), and does not exhibit unintended effects (humour, offence). (2007, 92)

Several important elements of the above definition need to be discussed. It is readily observable that a high priority is given to the language quality of a translation. In my view it does not refer only to the compliance with lexico-grammatical conventions of the TL. "A native-like text" also assumes that the TT patterns exhibit features of a similar text type written in the TL, i.e., that it exhibits the salient features of tourism discourse in English, as described in Section 2. In other words, a TT of good quality should not contain either "overt" or "covert" errors.

Another requirement postulated by Pierini's definition is that the TT follows both culturespecific genre conventions and the conventions of web textuality. The requirement that a translation of good quality should not produce unintended effects, such as humour and offence, is based on a generally accepted view that clumsy translations of tourism texts often provoke unintended humorous effects or may be offensive to members of the target culture. Numerous examples of unintended humour found in such translations circulate on the anecdotal level beyond translation scholars' circles.

\subsection{Criteria for Assessing Translation Quality of the TT}

Starting from the definition presented above, I formulated the following criteria to be used in the assessment of translation quality of the TTs in the corpus:

1. absence/presence of "overt" errors

2. attainment of functional equivalence between the ST and TT

3. use of cross-cultural mediation strategies ${ }^{5}$

4. web readability

The first three criteria are also in line with Munday's view of three main theoretical points in the discussion of translation of advertising texts: the focus on the target audience, the purpose or skopos of the translation, and the fact that adverts are a clear example of cross-cultural transfer $(2004,204)$. It should also be pointed out that Munday (2004, 206) concludes that "persuasive effect must remain a central concern for translators of adverts, and for translation theorists, too.” 
The first criterion, related to the correct use of the TL seems to be a self-explanatory category, which does not need to be further elaborated before it is operationalized in the analysis.

The second criterion refers to the relation of equivalence between a ST and its corresponding TT, conceived as the achievement of the same communicative purpose of the ST and TT. According to Pierini $(2007,91)$, the desirable relation of equivalence between the ST and TT is that of "pragmatic intertextual equivalence". As Pierini does not further elaborate this concept to show how it differs from "functional equivalence", advocated by the proponents of functionalist approaches, I have decided to use the term "functional equivalence", in an attempt to minimize terminological overlaps, not uncommon in Translation Studies. ${ }^{6}$ Returning to House's model (see Section 3), the desirable translation of a tourism text is an example of "covert translation", which requires the use of "cultural filters" to account for cultural differences between the two linguistic communities.

In terms of their textual functions, the texts in the corpus are "info-promotional" texts or materials. $^{7}$

The criterion of the use of cross-cultural mediation strategies refers to the mediation of SCspecific realia or exotisms, which have a specific function in tourism texts. Translators have to take into account that realia contribute to the dimensions of authenticity and strangerhood (see Dann 1996), and consequently have a specific role in tourism discourse.

The last criterion, website readability, is related to web communication and is usually emphasized as an important element of web design, which has an impact on how users process information. The standard definition of web readability found in the literature is "a measure of how easy it is for visitors to read and understand text on a web page" (https:// www.hotjar.com/conversion-rate-optimization/glossary/website-readability/). ${ }^{8}$

The rules on how to write for the web are based on empirical studies on how people actually read the texts on the web, with the main difference between reading printed texts and web texts being in that people scan the content on the web instead of reading it thoroughly. This insight leads to the demand for short, chunked texts as a standard in writing for the web. Experts on web usability have summed up their insights into a number of guidelines that recommend the use of highlighted keywords, meaningful subheadings, bulleted lists, and short paragraphs containing a single idea (see Garrand 2006).

As some of these elements are related to technical aspects of web design (for example, font size, line width and length and the use of typographical devices) and are not assumed to be in the domain of translators, in the analysis only language-related aspects of website readability will be examined: the length and complexity of sentences, segmentation of the text into chunks and the use of subheadings.

The term "functional equivalence" is also used by House and defined in the following way: "As a first requirement for this equivalence, it is posited that a translation text has a function equivalent to that of its source text" $(2015,23)$. See Valdeón (2009).

8 Similar definitions are found in other sources. For example, Rello, Pielot, and Marcos Rello (2016, n.p.) define readability as "the ease with which a reader can read and understand a written text". 


\subsection{The Corpus}

The sample of ST and TT pairs analysed consists of six pairs of texts related to gastronomy, published on Croatian tourist board websites. I decided to choose the websites of Croatian local tourist boards, which are subordinated to the national Croatian Tourist Board, and whose main task is to contribute to the promotion of tourism in their regions. The decision to select the texts from tourist board websites is based on the assumption that tourist boards, as official bodies whose explicit task is to promote tourist destinations, will pay closer attention to the textual material published on their websites than smaller, private-owned entities. For example, my preliminary research has shown that smaller, private-owned organizations often rely on Google Translate or do not even translate the content of their pages. Therefore, the websites of tourist boards are selected as examples of sites providing human translations. With regard to the choice of particular websites, I selected those of the destinations that were rated as the most successful in 2018 and 2019.?

In short, for the purposes of this research a relatively small corpus of six STs and six corresponding TTs was compiled. The SL corpus contains 1,182 words and the TL corpus 1,491 words. Detailed information regarding the corpus is presented in Table 1.

TABLE1. The corpus of STs and TTs analysed.

\begin{tabular}{|l|l|l|}
\hline Home Page & ST & TT \\
\hline www.istra.hr & $\begin{array}{l}\text { Top 5 istina o vinu iz Istre } \\
\text { (ST1) } \\
\text { (364 words) }\end{array}$ & $\begin{array}{l}\text { Top 5 Facts About the } \\
\text { Wine of Istria (TT1) } \\
\text { (470 words) }\end{array}$ \\
\hline www.kvarner.hr & $\begin{array}{l}\text { Gastronomija (ST2) } \\
\text { (131 words) }\end{array}$ & $\begin{array}{l}\text { Gastronomy (TT2) } \\
\text { (179 words) }\end{array}$ \\
\hline https://www.dalmatia.hr/ & $\begin{array}{l}\text { Gastronomija (ST3) } \\
\text { (48 words) }\end{array}$ & $\begin{array}{l}\text { Gastronomy (TT3) } \\
\text { (81 words) }\end{array}$ \\
\hline www.tzdubrovnik.hr & $\begin{array}{l}\text { Gastro \& lifestyle (ST4) } \\
\text { (331 words) }\end{array}$ & $\begin{array}{l}\text { Gastro \& Lifestyle (TT4) } \\
\text { (391 words) }\end{array}$ \\
\hline https://zadar.travel/hr & $\begin{array}{l}\text { Gradska tržnica (ST5) } \\
(208 \text { words) }\end{array}$ & $\begin{array}{l}\text { City Market (TT5) } \\
\text { (256 words) }\end{array}$ \\
\hline $\begin{array}{l}\text { https://www.hvarinfo.com/hr/ } \\
\text { gastronomija-i-restorani-na-hvaru.html }\end{array}$ & $\begin{array}{l}\text { Hvar (ST6) } \\
(100 \text { words) }\end{array}$ & $\begin{array}{l}\text { Hvar (TT6) } \\
\text { (114 words) }\end{array}$ \\
\hline
\end{tabular}

\section{Results}

\subsection{Absence/Presence of "Overt" Errors}

In his section I analyse the problems related to the correct use of English, i.e., the presence of obvious language mistakes. Typos and grammar mistakes create the impression of unprofessional translation. The chunk of the text on the city market in Zadar (TT5) illustrates this kind of errors:

\footnotetext{
9 According to the data published by the Croatian Bureau of Statistics, the counties that registered the highest numbers of tourists in 2018 and 2019 were Istria County, the Primorje-Gorski kotar County, Split-Dalmatia County, DubrovnikNeretva County and Zadar County (https://www.dzs.hr/Hrv_Eng/publication/2019/04-03-02_01_2019.htm).
} 


\section{Example 1}

Tržnica na Poluotoku zajedno s ribarnicom, smješteni pod povijesnim Bedemima zadarskih pobuna koji su na UNESCOvoj liste svjetske baštine, zato je odavno neodvojiv dio zadarskog urbanog identiteta.
The market, together with the fish market on the Peninsula, are located below the historical City Walls that are a part of the UNESCO World Heritage List. That's exactly why they are an inseperable part of the urban identity of Zadar.

The TT contains an obvious spelling mistake (inseperable), a grammar mistake (the plural of the verb "be" are located instead of is located), the latter probably being a consequence of the mechanical copying of the Croatian plural smjesteni into English and an unidiomatic expression (are a part of the UNESCO World Heritage List). Nevertheless, while these elements definitely do not enhance the impression of the TT, it cannot be claimed that they lead to the break in communication. Similar overt errors are found in another chunk from ST5-TT5.

\section{Example 2}

Kakva graja i kakvo šarenilo. Kupuje se i prodaje na svim mogućim jezicima - pisao je još 1888. godine pariški putopisac Pierre Bauron.
What a chitchatter, what a variety. People buy and sell in all sorts of languages - noted in the early 1888 by the travel writer Pierre Bauron.

In Example 2, the incorrect use of the definite article before the year 1888 can be observed. However, in addition to this, the TT contains an error in the rendering of the precise meaning of the ST. The Croatian adverb još in pisao je još 1888. godine does not refer to the beginning of the year but to the fact that the French travel writer made the quoted observation as long ago as 1888. Therefore, the correct rendering in English is noted/wrote as long ago as 1888. The function of this segment of the ST is to emphasize that the history of tourism in Zadar, and consequently the appeal of Zadar as a tourist destination, goes far back in time. Consequently, in the TT this aspect is toned down.

The chunk quoted in Example 2 raises some other issues in addition to the breach of grammatical rules. The word chitchatter (or chitter-chatter) refers to light, informal conversation. The Croatian word graja refers to a state of great, noisy activity. The English lexical repertoire has several possibilities which aptly convey the intended meaning: hustle and bustle, hubbub, hurly-burly etc. The reference to the author of the quotation, Pierre Bauron from Paris, is rendered without the mention of his origin. It is assumed that for the TT reader the reference to Bauron does not have much relevance, which makes this omission acceptable, particularly if we keep in mind the need to prevent information overload (see Section 3.1). Šarenilo literally means diversity or variety, but in Croatian this word has strong connotations of liveliness and colourfulness. It is used in the ST, instead of raznolikost or šarolikost, to emphasize the abundance of various colourful products offered on the market stalls. By the use of variety (the quality of not being the same, uniform or monotonous) for šarenilo the intended effect is again downplayed. The suggested translation, which would aim to achieve the same effect as the ST might be: What a hustle and bustle! How colourful and lively! People sell and buy in all languages of the world - wrote French travel writer Pierre Bauron as long ago as 1888. 
In Example 3 I will focus both on obvious language mistakes ("overt errors") but also on the adaptation of the TT to the generic conventions of tourist promotional texts written in the TL ("covert errors").

\section{Example 3}

Na izgled sasvim običan kolač, torta boje čokolade ili pak krema, ničim ne odaje zagonetni sastojak.

Tek nakon nekoliko trenutaka, ako duboko udahnete, osjetiti céte možda čak i nepoznati erotični miris koji mami zalogaj.

U okusu hvarske lavande osjetiti ćete svu draž i ljepotu otoka Hvara, božansku snagu i užitak.
On the first look just an regular cake with an colour of chocolate or cream does not reveal the secret flavour.

Only after few moments if you breathe deeply you will sense maybe even unknown erotical smell which makes you want for more.

In the taste of Hvar lavander, you will sense the beauty and the strength of the island.

Three chunks of Croatian text presented in Example 3 are extracts from ST 6, in which the "Lavender cake", a specialty of the island of Hvar is described, with a clear intention of persuading the reader to taste the cake. The text in English abounds in elementary language mistakes, such as the use of an before regular and colour, the omission of the indefinite article before few moments and the clumsy word order in Only after few moments if you breathe deeply you will sense... instead of If you breathe deeply (or better if you take a deep breath) after a few moments.... Grammatical errors can also be noticed in the Croatian ST (consistent use of osjetiti ćete instead of osjetit cete). At the lexical level, errors that seriously compromise the rendering of the intended message are observed. The intention of the first sentence in Example 3 is to say that the cake does not grab attention by its appearance, but that what makes this seemingly ordinary cake special is the "mysterious ingredient", i.e., lavender. Therefore, ordinary instead of regular, betray instead of reveal and ingredient instead of flavour should have been used. Further, in the second chunk Tek nakon nekoliko trenutaka, ako duboko udahnete...is clumsily rendered because of the word order literally transferred from the Croatian ST. In addition, a nuance related to the sweet aroma of lavender, osjetiti cete možda čak i nepoznati erotični miris koji mami zalogaj is inadequately rendered, due to the literal transcoding of the words. The suggested improvement would be If you take a deep breath, after a few moments you'll feel the erotic, maybe unfamiliar erotical scent, which will (surely) make you take a bite!!

The sentence making up the last chunk of the ST is translated in the manner that downplays the intended effect of the ST, i.e., the creation of the sense of euphoria, an important feature of the language of tourism (see Section 2). The lexical elements used in the ST draż i ljepotu otoka Hvara, božansku snagu i užitak are not rendered in the TT, but omitted in the simplified translation. The rendering which would preserve these features might be: The taste of Hvar lavander will let you feel all the charm and beauty of the island of Hvar, its divine strength and allurement.

Example 4, taken from the webpage of the Tourist Board of Splitsko-Dalmatinska županija (ST3-TT3), illustrates the translation in which "overt" errors result in the incomprehensible segment of the TT. 
U uskoj vezi s geografskim bogatstvom

Splitsko-dalmatinska županije je i bogatstvo njene gastronomije. Na nevelikom području susrécu se suprotnosti prožimajuci okuse prošlih vremena $i$ kreativne kubinje današnjice; arome netaknute prirode s dva zrna soli...
Geographical richness of Split-Dalmatia County is closely related to the wealth of its gastronomy. On a small area there are facing the contradiction of past time flavor and the creative cuisine of today; aroma of pristine nature with two grains of salt...

The ST sentence in italics means that many contrasts co-exist on a relatively small geographical area because the flavours of the past are merged with today's creative cuisines. The rendering in the TT On a small area there are facing the contradiction of past time flavor and the creative cuisine of today seems to be a segment of un-postedited machine translation, making hardly any sense in English. The suggested translation might be: On this small area you'll find so many contrasts as the flavours of the past times mix with today's creative cuisines.

\subsection{Achievement of Functional Equivalence}

The criterion of functional equivalence enables us to pinpoint covert errors in the TTs. This means that these elements do not constitute a breach of the TL norms but rather mismatches in the dimensions of register and genre.

ST1, published on the website of the Tourist Board of Istria, is an example of the consistent use of rhetorical devices typical for info-promotional texts, which facilitates the translator's need for interventions. As can be seen in Example 5, the reader is repeatedly and directly addressed through the use of questions and imperatives, and is thus invited to take part in the suggested activities.

\section{Example 5}

Jeste li probali istarsku malvaziju, teran,...?

Jeste li znali da je vino, pogotovo ono crno, jako dobro za vaše zdravlje?

Saznajte koji wellness hoteli nude ovaj pomlađujući tretman.
Have you ever tried Istrian Malvasia, Teran,...?

Did you know that wine, especially the red one, can benefit your health?

Find out which wellness hotels offer this rejuvenating treatment.

Example 5 shows that the translator of TT1 closely followed syntactic structures used in ST1, and consequently produced the TT that fulfils its communicative purpose in the TL.

Other STs in the corpus do not exhibit consistent use of rhetorical devices that are expected to be used in the similar texts in the TL. However, it is particularly interesting to note that in such cases the translators did not intervene trying to adapt the text but literally followed the ST. Example 6 illustrates this claim. 
Example 6

Posjetitelji domaćih konoba žele kušati izvorna domaća jela, dobar pršut, sir iz ulja, salatu od hobotnice....
Those visiting local taverns wish to taste authentic national food, good smoked ham, cheese kept in oil, octopus salad....

As can be seen in Example 6, an extract from a text published on the website of the Tourist Board of the Dubrovnik-Neretva County (ST4) contains a declarative statement in which a number of local specialties on offer in Dubrovnik restaurants is listed. TT4 follows closely the ST's syntactic structure, more suitable for informative texts and lacking persuasive force. In the TT sentence a question or an imperative, both forms directly addressing the readers, could have been used, which would enhance the persuasive force of the entire text. For example, Have you tasted...?" or Visit local taverns and taste....! In the other TTs, which cannot be extensively quoted, a lack of adaptation to the conventions of English tourism discourse is evident in the use of expressions belonging to formal register. For example, in the following chunk from TT2 Whatever cravings you might have, rest assured that you will find a delicious, healthy meal definitely worth your visit, and your return, in which readers are directly addressed, the phrase rest assured, which belongs to the formal register, is to be noticed. Also, contracted forms such as you'll instead of you will, a strong indicator of informality, are not used.

I will return to Example 6 to show that the translator did not adapt the TT to the features of English tourism discourse with regard to the use of adjectives, a very important lexical-level feature of tourism texts (see Section 2). Thus, dobar pršut is translated as good smoked ham. In order to adjust the TT to the norms of info-promotional material written in English, good could be replaced with an adjective that has more persuasive force, such as fabulous, delicious, most delicious, tasty, etc.

\subsection{Use of Cross-Cultural Mediation Strategies}

In this part I will focus on cross-cultural mediation strategies used to render exotisms (see Nord 1991), abundantly used in tourism promotional materials. As all the texts making up the corpus are related to gastronomy, the majority of such references are names of local foods and dishes, as well as typical tools and utensils. The translator is faced with the challenge of how to render them in the TT. In the corpus the most frequently used strategy is retaining the reference in its original form with an addition of an explanation in brackets. Example 8 illustrates the constraints faced by translators in such cases.

\section{Example 7}

[...] arome netaknute prirode s dva zrna soli, koju je preko brda nabacilo jugo, ili miris komastre i komina donesen burom. aroma of pristine nature with two grains of salt, thrown over the hill by the south wind, or the smell of komin (a fireplace) and komaštre (a chain and a hook for hanging cooking pots over the fire on the fireplace) brought by the northern wind.

At first glance, it is noticeable that the TT is substantially longer than the ST, owing to the explanations added in brackets by the translator. Komastra and komin are strongly coloured 
dialectal expressions used in the ST to enhance the impression of authenticity. They are retained in the TT, at the risk of information overload on the one hand, and on the other of producing a text not suited to the requirements of web textuality. It is also interesting to note that the translator did not pay attention to the fact that in the English text the word komastra instead of komastre (the form for the genitive case) should be used, as English does not have morphological forms for grammar cases.

Another interesting example of the use of this strategy is given below.

\section{Example 8}

Još jedna posebnost Istre je da se $s$ teranom priprema istarska supa, tradicionalni napitak spečenim kruhom, malo papra, šcéera $i$ maslinovog ulja u bukaleti, izvrsna za hladne ili kišovite zimske dane kada se uz ognjište okupe prijatelji i obitelj.
Another specialty of Istria is the preparation of "Istrian supa" (soup) with Teran, traditional meal with the baked bread, a little bit of pepper, sugar and olive oil in "bukaleta" (an Istrian pitcher).

It is a perfect meal during colder or rainy winter days when friends and family can gather around the fireplace.

While the segment is correctly translated, the problem of istarska supa is not adequately solved. The ST contains a description of the dish, as the author assumed that SL speakers would also need an explanation of what istarska supa is. While the ST clearly says that istarska supa is a traditional beverage (tradicionalni napitak), in the TT it is rendered as a traditional meal, which may be dangerously misleading for TT readers, who will probably expect that they will be served a meal. The problem for the translator might have been caused by the misconception that the Istrian dialect word supa is related to soup (juha in Croatian). However, the word stems from the dialectal expression supati, which means to toss. Actually, istarska supa is a drink made of wine and olive oil which is drunk from bukatela while some toasted bread is tossed in it.

\subsection{Web Readability}

An example illustrating the problems related to web readability is taken from ST2-TT2 (Example 10). Both texts are divided into rather large chunks with no subheadings. As can be seen in Example 9, the sentences are quite long and complex.

\section{Example 9}

Primorska kuhinja kao i kuhinja njegovih otoka temelji se na ribi, morskim plodovima, voću i povrću te, dakako, maslinovom ulju. (20 words) Uz ove zajedničke karakteristike, tu je još i cijeli niz osobitosti pa ćete u svakom kraju uživati i u ponekom lokalnom specijalitetu. (23 words)
The cuisine of the coastal area (Primorje) and the islands is based on fish, seafood, fruit and vegetables and, of course, olive oil. (23 words). In addition to these common features, there is a whole range of particular features characteristic of different areas, so that each particular area will offer you the possibility of savoring a few local specialties as well. ( 35 words) 
The second sentence in the TT (35 words) does not comply with readability standards, although it could be adapted by the translator to do so by splitting it into two sentences and omitting certain redundancies. For example, The cuisine of the coastal area (Primorje) and the islands is based on fish, seafood, fruit and vegetables and, of course, olive oil. Different areas offer their unique local specialties. So make sure you try them all.

\section{Conclusion}

The aim of this study was to explore the quality of tourism text translations from Croatian into English published on the web, taking into account the specific features of translating for the web on the one hand, and on the other of translating tourism promotional texts. The proposed criteria were applied to the corpus of Croatian STs and English TTs published on the websites of Croatian Tourist Boards. The analysis applying the proposed criteria revealed that the TTs exhibit a number of overt errors, i.e., easily noticeable elementary language mistakes. Further, "covert errors" or mismatches on the level of tailoring a TT to comply with the conventions of TL tourism promotional materials (personalization, the desired (in)formality and the persuasive force of a TT) and with the conventions of web readability were observed. To avoid such mismatches translators have to introduce more radical changes into the text. Though the corpus analysed is relatively small, it is still large enough to provide an insight into the patterns of translators' decisions and to allow for the conclusion that the translators of the TTs were unwilling or unable to leave the "safe haven of a 'straight translation"' (Smith and Klein-Braley 1997, 175), often not producing functionally equivalent TTs.

\section{References}

Agorni, Mirella. 2012. "Questions of Mediation in the Translation of Tourist Texts." Altre Modernità: 1-11. https://doi.org/10.13130/2035-7680/1963.

—. 2016. "Tourism Across Languages and Cultures: Accessibility Through Translation." Cultus 9: 13-27.

Calvi, Maria Vittoria. 2006. Il linguaggio spagnolo del turismo. Viareggio-Lucca: Mario Baroni editore.

Cappelli, Gloria. 2006. Sun, Sea, Sex and the Unspoilt Countryside. How the English Language Makes Tourists Out of Readers. Pari: Pari Publishing.

—. 2008. "The Translation of Tourism-Related Websites and Localization: Problems and Perspectives." In Voices on Translation: Linguistic, Multimedia, and Cognitive Perspectives, edited by Annalisa Baicchi, 97-115. Roma: Bulzoni Editore.

Colina, Sonia. 2020. “Quality.” 2020. In The Routledge Encyclopedia of Translation Studies, edited by Mona Baker and Gabriela Saldanha, 458-63. London: Routledge.

Dann, Graham. 1996. The Language of Tourism. A Sociolinguistic Perspective. Oxford: CAB International.

Denti, Olga. 2015. "Gazing at Italy from the East: A Multimodal Analysis of Malaysian Tourist Blogs."

Lingue Culture Mediazioni - Languages Cultures Mediation (LCM Journal), [S.1.], 2 (1): 47-68.

https://doi.org/10.7358/lcm-2015-001-dent.

Depraetere, Ilse, ed. 2011. Perspectives on Translation Quality. Berlin: Walter de Gruyter.

Drugan, Joanna. 2013. Quality in Professional Translation: Assessment and Improvement. London: Bloomsbury.

Duff, Alan. 1981. The Third Language: Recurrent Problems of Translation into English. Oxford: Pergamon Press.

Durán Muñoz, Isabel. 2011. "Tourist Translations as a Mediation Tool: Misunderstandings and

Difficulties." Cadernos de Tradução 27 (1): 29-49. https://doi.org/10.5007/2175-7968

$.2011 \mathrm{v} 1 \mathrm{n} 27 \mathrm{p} 29$.

—. 2019. "Adjectives and Their Keyness: A Corpus-Based Analysis of Tourism Discourse in English."

Corpora 14 (3): 351-78. https://doi.org/10.3366/cor.2019.0178. 
Fox, Renata. 1999. “Jezik turizma: retorika kvalitete.” In Teorija i mogućnosti primjene pragmalingvistike, edited by Lada Badurina, Nada Ivanetić, Boris Pritchard, and Diana Stolac, 225-32. Zagreb: Hrvatsko društvo za primijenjenu lingvistiku.

- 2004. "Gastrospeak: Towards Gastronomic Identity of Croatian Tourism." In Strategic Partnerships for the Development of Tourist Destinations, edited by Milan Ambrož, 1-11. Portorož: Visoka šola za turizem.

—. 2007. "Reinventing the Gastronomic Identity of Croatian Tourist Destinations." International Journal of Hospitality Management 26 (3): 546-59. https://doi.org/10.1016/j.ijhm.2006.03.001.

Francesconi, Sabrina. 2008. "Metaphors of Jewels as Strategies of Persuasion in British Tourist Promotional Texts." In Language and Bias in Specialized Discourse, edited by Guliana Garzone and Paola Catenaccio, 176-86. Milano: CUEM.

-. 2014. Reading Tourism Texts: A Multimodal Analysis. Bristol: Channel View Publications.

Gandin, Stefania. 2016. "Teaching and Learning the Language of Tourism as an LSP: Corpus-Based Approaches." In New Insights into Corpora and Translation, edited by Daniel Gallego-Hernández, 93-111. Newcastle upon Tyne: Cambridge Scholars Publishing.

Garrand, Timothy. 2006. Writing for Multimedia and the Web: A Practical Guide to Content Development for Interactive Media. 3rd ed. Amsterdam: Elsevier.

Gotti, Maurizio. 2006. "The Language of Tourism as Specialized Discourse.” In Translating Tourism:

Linguistic/Cultural Representations, edited by Oriana Palusci and Sabrina Francesconi, 15-34. Trento: Università degli Studi di Trento.

Hatim, Basil. 2004. "Culture as Textual Practices: The Translation of the Tourist Brochure as a Genre." In Pragmatics at Work: The Translation of Tourist Literature, edited by María Pilar Navarro Errasti, Rosa Lorés Sanz, and Silvia Murillo Ornat, 15-27. Bern: Peter Lang.

Hickey, Leo. 2004. "Perlocutionary Pursuits: Persuading of/that/to." In Pragmatics at Work: The Translation of Tourist Literature, edited by María Pilar Navarro Errasti, Rosa Lorés Sanz, and Silvia Murillo Ornat, 57-79. Bern: Peter Lang.

House, Juliane. 1997. Translation Quality Assessment: A Model Revisited. Tübingen: Narr. House.

-. 2015. Translation Quality Assessment. Past and Present. London: Routledge.

Janoschka, Anja. 2004. Web Advertising: New Forms of Communication on the Internet. Amsterdam: John Benjamins.

Kelly, Dorothy. 1997. "The Translation of Texts from the Tourist Sector: Textual Conventions, Cultural Distance and Other Constraints." Trans 2: 33-42. https://doi.org/10.24310/TRANS.1998.v0i2 .2354 .

Manca, Elena. 2016. Persuasion in Tourism Discourse: Methodologies and Models. Newcastle upon Tyne: Cambridge Scholars Publishing.

Mocini, Renzo. 2005. "The Verbal Discourse of Tourist Brochures." AnnalSS 5: 153-64.

—. 2013. "The Promotional Functionality of Evaluative Language in Tourism Discourse." Lingue Linguaggi 9: 157-72. https://doi.org/10.1285/i22390359v9p157.

Munday, Jeremy. 2004. “Advertising: Some Challenges to Translation Theory.” The Translator 10 (2): 199219. https://doi.org/10.1080/13556509.2004.10799177.

Nigro, Maria Giovanna. 2005. "The Language of Tourism as LSP? A Corpus-Based Study of the Discourse of Guidebooks." In Modern Approach to Terminological Theories and Applications, edited by Heribert Picht, 187-98. Bern: Peter Lang.

—. 2012. "From Words to Keywords: The Journey from General Language to the Language of Tourism." Textus. English Studies in Italy 25 (1): 105-19.

Newmark, Peter. 1991. About Translation. Clevedon: Multilingual Matters.

-. 1993. Paragraphs on Translation. Clevedon: Multilingual Matters.

Nord, Christiane. 1991. Text Analysis in Translation: Theory, Methodology, and Didactic Application of a Model for Translation Oriented Text Analysis. Amsterdam: Rodopi.

Pierini, Patrizia. 2007. "Quality in Web Translation: An Investigation into UK and Italian Tourism Web Sites." The Journal of Specialized Translation 8: 85-103. https://jostrans.org/issue08/art_pierini.pdf. —. 2009. "Adjectives in Tourism English on the Web: A Corpus-Based Study." CÍRCULO de Lingüistica Aplicada a la Comunicación 40: 93-116. 
Rello, Luz, Martin Pielot, and Mari-Carmen Marcos. 2016. "Make It Big!: The Effect of Font Size and Line Spacing on Online Readability." In Proceedings of the 2016 CHI Conference on Human Factors in Computing Systems. New York: Association for Computing Machinery. https://doi.org/10.1145 /2858036.2858204.

Snell-Hornby, Mary 1999. "The 'Ultimate Confort': Word, Text and the Translation of Tourist Brochures." In Word, Text, Translation: Liber Amicorum for Peter Newmark, edited by Gunilla Anderman and Margaret Rogers, 95-104. Clevedon: Multilingual Matters.

Smith, Veronica, and Christine Klein-Braley. 1997. "Advertising - A Five-Stage Strategy for Translation." In Translation as Intercultural Communication: Selected Papers from the EST Congress, Prague 1995, edited by Mary Snell-Hornby, Zuzana Jettmarová, and Klaus Kaindl, 173-84. Amsterdam: John Benjamins.

Sulaiman, Zain, and Rita Wilson. 2019. Translation and Tourism: Strategies for Effective Cross-Cultural Communication. Singapore: Springer Nature Singapore.

Sumberg, Carolyn. 2004. "Brand Leadership at Stake: Selling France to British Tourists." The Translator 10 (2): 329-53. https://doi.org/10.1080/13556509.2004.10799183.

Valdeón, Roberto A. 2009. "Info-Promotional Material Discourse and Its Translation: The Case of the Asturian Tourist Board Texts." Across Languages and Cultures 10 (1): 21-47. https://doi.org/10.1556 /Acr.10.2009.1.2.

Van Westering, Jetske 1999. "Heritage and Gastronomy: The Pursuits of the 'New Tourist'." International Journal of Heritage Studies 5 (2): 75-81. https://doi. org/10.1080/13527259908722252.

Yui Ling Ip, Janice. 2008. "Analyzing Tourism Discourse: A Case Study of a Hong Kong Travel Brochure." LCOM Papers 1: 1-19. 